\title{
Political Corruption, Government Legitimacy and Democracy in Nigeria, 1999 - 2015
}

\author{
Monday Aliu, \\ Department of Political Science, \\ Kogi State University, Anyigba, Kogi State, Nigeria
}

Doi:10.19044/esj.2019.v15n26p126 URL:http://dx.doi.org/10.19044/esj.2019.v15n26p126

\begin{abstract}
The paper examined the effects of corruption among public officials and political leaders on government legitimacy and democracy in Nigeria between 1999 and 2015. The paper, which adopts documentary and qualitative descriptive methods in collecting and analyzing the relevant data, is underpinned by the elite theory. The contention of the paper is that endemic corruption in the polity can be situated among the ruling elites who control political power and resources. In the context of the power relations framework, state powers are manipulated and appropriated to amass resources and sustain networks of relationships core to consolidating elites hold on power as well as perpetuating the subordination of the un-elite majority. The finding from the paper shows that political corruption undermined the ability of government to deliver public goods and services, contributing in part to the decline in popular trust in government, institutions, processes and the attendant dissatisfaction with the political system in Nigeria during the period. The paper recommends that the political leadership in Nigeria needed to reconsider their present kind of politics which focuses more on money and self for a service oriented politics. This will enhance the rule of law, popular participation in governance, governmental accountability and legitimacy; and thereby halt the slide towards political authoritarianism and democratic reversal in Nigeria.
\end{abstract}

Keywords: Political corruption, Government, Legitimacy, Democracy, Public officials, Ruling elites

\section{Introduction}

Since the return to democratic governance on May 29, 1999, the scourge of widespread corruption among public officials continues to pose serious threat to democracy and development in Nigeria (Aliu, 2013; Aliu, 2018). The state centric concept of corruption as the 'misuse of public office for personal gain' (Klitgaard, Maclean-Abaroa \& Paris, 2000: 2) suffices in 
the paper. However, it is important to stress that beyond self interest, public officials and political leaders do abuse public funds and resources as well as their offices for the benefits of their communities, political parties, religious and ethnic groups (Gardiner, 2009). The prosecution of corruption cases involving most public officials in Nigeria tends to confirm this development. In most cases, public funds, power, institutions, policies, legislations and decisions are misused by public officials to promote community and social courses that boost their personal egos and enhance their public status.

The minimalist perspective on democracy which the paper adopts is 'that institutional arrangement for arriving at political decisions in which individuals acquire the power to decide by means of a competitive struggle for the people's votes' (Schumpeter, 2011: 269). In a democracy, 'the people have the opportunity of accepting or refusing the men who are to rule them' (Schumpeter, 2011: 271) through free, fair, competitive and credible elections. The minimalist electoral democracy is largely concerned with providing the minimum conditions of freedoms conducive for elite struggle for the vote of the people (Schumpeter, 2011) as against the 'popular control over government' (Grugel, 2002: 14) attribute of classical democracy. Moreover, the transitional nature of democracy in the country during the period under review underscores the essence and appropriateness of the minimalist democratic values of elections, institutions, political and civil freedoms and rule of law towards the democratization process in Nigeria.

Corruption among public officials is antithetical to the democratic spirit and values. It is in this context that Diamond (2008) argued that political corruption is prevalent in any political system that have disregard for the values of accountability, transparency, probity, rule of law, strong and independent institutions and popular participation of citizens in governance. The implications of widespread mismanagement and misappropriation of public funds as well as abuse of offices by public officials on democracy can be devastating. With regards to government legitimacy, an important democratic variable, political corruption can contribute in part to decline in public trust in government and government policies, and undermine popular confidence in politicians, processes and institutions, resulting in disillusionment with the political system (Diamond, 2008; Aliu, 2013).

Public trust in the performance and institutions of government is critical to democratic stability and consolidation (Diamond, 2008). The transitional nature of democracy in Nigeria makes the focus on institutional and governmental legitimacy imperative. The expression of deep frustration by Nigerians about widespread political corruption raises concerns about citizens' confidence in government and the legitimacy of the political system. It is against this background that the study examines the effects of widespread corruption among public officials and political leaders on government 
legitimacy and democracy in Nigeria between 1999 and 2015. To achieve this objective, the paper in addition to the introduction consists of the theoretical framework, the problem of political corruption in Nigeria, overview of political corruption and government legitimacy, political corruption, government legitimacy and democracy in Nigeria, and conclusion.

\section{Theoretical Framework}

The study adopts the elite theory as theoretical framework of analysis, given the ability of the theory to explicate 'from the realist perspective the workings of modern democracy which focuses on representative democracy' (Omodia, 2011: 112). Elites are 'actors controlling resources, occupying key positions and relating through power networks' (López, 2013:3). Elitism, as a theory on democracy and the state, seeks to describe and explain the power relationships in modern societies. The basic argument of the theory is that 'a small minority consisting members of the economic elite, policy planning networks and military institutions holds the most power in any society'(Ekundayo, 2017: 1).

The works of Vilfredo Pareto - Law of Elite Circulation (1848-1923), Gaetano Mosca - Political Class (1858-1941) and Robert Michels - Iron Law of Oligarchy (1876-1936) contributed immensely to the groundwork on the theory and praxis of elitism. The central thesis of the elitism is that politics in any society is a relationship between rulers and the ruled. The power relations is one in which the ruling elites, as an organised minority, are highly influential and possesses superior intellectual, moral and material resources, which allow them to dominate the processes surrounding the acquisition, use and consolidation of state power when compared to the unorganised and un-elite majority (Ekundayo, 2017). However, the theory has been criticised for promoting the selfish use of political power by the minority ruling elites.

The dominance of political power by the minority ruling elites within the context of the power relations seems to reinforce the 'understanding that representative democracy is a function of the dictates and manipulations of the elites based on class organization and acquisition of political skill' (Omodia, 2011: 112). The realisation that the ruling elites are willing to 'do everything to secure, conserve, preserve and perpetuate its power over a majority that is largely unorganized' (Ekundayo, 2017) tends to confirm this reality. In essence, any means and methods, not minding its conformity with the rule of law, could be deployed by the ruling elites to fulfil their selfish interest of monopolizing state power. Invariably, the relationship between rulers and the ruled in the society is defined by power, with the ruling elites producing the power elites that eventually control state power (Ekundayo, 2017).

The complex nature and outcome of the power relations between the ruling elites and the un-elite majority explored so far is largely obtainable in 
Nigeria. It is in this regard that Omodia (2011: 112) argued that 'the greatest threat to the survival of the Nigerian state is the elitist contradiction associated with the competition for political offices by the political elites'. The irresponsibility of the ruling elites mostly contributes to the challenges of governance and development, especially the problem of widespread corruption confronting Nigeria (Okeke and Idike, 2016). The political leadership and ruling elites remains a major obstacle to development and democracy in Nigeria (Aliu, 2014).

The unsavoury roles of the ruling elites during the contestation for political power, as well as use and consolidation of state power is germane to understanding the prevalence of corruption among elected and appointed office holders in Nigeria. In the context of the power relations, elite capture of state power and drive to perpetuate their hold on power at all cost is one of the realities of post colonial Nigeria and indeed Africa. Significantly, the culture of impunity, lawlessness, mismanagement of state resources and abuse of office is one of the absurd manifestations of the elite capture of state power in Nigeria and Africa (Aliu, 2014). Besides, the issue of maintenance of network of relationships by the ruling elites, a key assumption of the elite theory, underscores the power relationship in Nigeria. The endemic culture of personalisation of state power means that political leaders treat their offices as personal properties and use the law and state institutions to pursue their personal agenda in Nigeria. In the process, state power and resources are deployed to sustain network of relationships and maintain political support and patronage (Joseph, 1991; Diamond, 2008; Aliu, 2013).

Besides, in the quest to amass wealth and resources, so as to further their control of state power and maintain network of relationships core to their hold on political power 'the political class in Nigeria regards politics as a means to make money and the state as the instrument to economic survival' (Aliu, 2013: 104), 'a clearing house for jobs', contracts and official plunder' (Joseph, 1991: 10). Consequently, most ruling elites and political leaders largely appropriate state power, offices, resources, institutions, policies and laws to accomplish the aforementioned selfish quests and drives, relegating to the background the popular desires of the citizens for democratization and development. The assertion by Szeftel (2000:302) that 'corruption and class formation rest on prebendalism, on the control and use of state position and state power and office, once acquired must be held, sometimes by whatever means necessary' readily explains the intricate connection between the activities of the ruling elites and the problem of widespread corruption in Nigeria. 


\section{The Problem of Political Corruption in Nigeria}

Political corruption is one of the problems Nigeria has been grappling with since the return of democracy in 1999. Corruption is widespread among political leaders and public officials in Nigeria (Aliu, 2011, Aliu 2013, Aliu, 2018; Adesina, 2016). Political leaders are known to engage in bribery, cronyism, award of phony contracts, nepotism, inflation of contract sums, misappropriation of public assets, stealing of government funds, embezzlement, electoral fraud, and extortion in Nigeria (Aliu, 2013; Adesina, 2016). The prevalence of political corruption made the global anti-corruption agency Transparency International (TI) to consistently rank Nigeria as one of the highly corrupt nations in the world in its annual Corruption Perception Index (CPI) between 1999 and 2015. The pervasiveness of corruption in the polity is summarised by the assertion that 'in Nigeria it is not only that officials are corrupt, but that corruption is official' (David-West in Aliu, 2018: 145).

The investigative and prosecutorial activities of the Economic and Financial Crime Commission (EFCC), the anti-corruption agency in Nigeria has resulted in scandalous revelations on the status of public officials and political leaders - which cut across the various tiers and arms of government as well as party affiliations, allegedly involved in corrupt practices as well as those convicted of stealing public funds. For example, in 2008, the EFCC arrested and arraigned the daughter of ex-President Olusegun Obasanjo, Senator Iyabo Obasanjo for receiving N10 million (10 Million Naira) from the Senate Committee on Health unspent budget of 2007 (Alabi and Fashagba, 2010; Aliu, 2013). Similarly, in 2009, the EFCC arrested and arraigned Honorables Ndudi Elumelu, Paulinus Igwe and Mohammed Jibo for their alleged involvement in N5.2billion (Five billion, Two Hundred Million Naira) power contract fraud while performing oversight functions as members of the lower house of representatives (Alabi and Fashagba, 2010; Aliu, 2013).

The Human Right Watch (2011) reported that in 2005, Diepreye Alamieyeseigha, the ex-governor of Bayelsa State was impeached and convicted for misappropriation of public fund totaling $\$ 55$ million while in 2008, Lucky Igbinedion, the former governor Edo state was convicted of embezzling more than $\$ 25$ million of public fund. Also, the BBC (2012) reported that James Ibori, who was a former governor of Oil rich Delta State, was convicted in Britain of stealing almost $£ 50$ million belonging to the State. In 2009, Bode George, who is a chieftain of the People's Democratic Party, the former ruling party in Nigeria and ex-chairman of the Nigerian Ports Authority (NPA) was convicted along with five other persons for fraud amounting to N100 billion and sentenced to two years in Jail (Thisday, 2011).

The President Muhammadu Buhari administration unravelled some alleged corruption cases that happened under the government of former President Jonathan which ended on May 29, 2015. For example, Sambo 
Dasuki, the ex-National Security Adviser (NSA) to the former president and four other persons are being prosecuted for allegedly laundering and diverting $\$ 2.1$ billion (N546 billion) meant for the purchase of arms for the military to combat the Boko Haram insurgency and other security threats in the country (Adesina, 2016). Also, the former Director-General of the Nigeria Maritime Administration and Safety Agency (NIMASA), Patrick Ziadeke Akpobolokemi and five other staff of the agency were arrested and arraigned in 2015 by the EFCC for stealing N2.6 billion belonging to the agency. Similarly, the EFCC declared Alhaji Abdurasheed Maina wanted in 2015 over the allegation of misappropriating and mismanaging N195 Billion pension fund (Adesina, 2016).

It is important to note that the amount of public fund reportedly lost to corruption among public officials in Nigeria varies. According to Amundsen (in Adesina, 2016) Nigeria has lost public funds of between US\$300 and US $\$ 400$ billion to corruption since independence in 1960. Meanwhile, the former Chairman of the EFCC, Nuhu Ribadu, observed that Nigeria lost an estimated US\$380 billion between 1960 when the country attained independence and 1999 when military dictatorship came to an end (Adesina, 2016). In the same vein, Nigeria was reported to have lost an average of $\$ 4$ billion - \$8 billion to corruption between 1999 and 2007 (Mustapha, 2010; Aliu, 2013). Similarly, The Global Financial Integrity (GFI), an international illicit financial outflow watchdog, reported that an estimated US\$89.5 billion was stolen from the state coffer between 1970 and 2008 by political leaders in Nigeria (Adesina, 2016). The implications of the huge losses of public funds to corruption on democracy and development no doubt can be deleterious.

\section{Overview of Political Corruption and Government Legitimacy}

The stability and sustenance of a democratic government depend on its legitimacy (Diamond, 2008). Legitimacy according to Lipset (1959: 86) 'involves the capacity of a political system to engender and maintain the belief that the existing political institutions are the most appropriate or proper ones for the society'. Furthermore, the legitimacy of a regime thrives on the acceptance by the people of its 'moral rights to make laws, collect taxes, direct resources and command obedience' (Lipset in Diamond, 2008: 88). Therefore, the people's support for democracy, satisfaction with the way democracy works and performance of government are essential for democratic legitimacy and stability (Afrobarometer, 2006). Democracy is vulnerable to collapse as public trust in government performance and institutions decreases. This is because anti-democratic forces are quick to exploit government loss of public support to their advantage thereby engendering a slide towards authoritarianism and dictatorship (Diamond, 2008). 
Political corruption undermines the attainment of public policy and the rule of law (World Bank, 1997). Political corruption repudiates the democratic values of accountability, transparency, equality and popular participation in government and retard development (Inokoba and Ibegu, 2011). Thus, political corruption has adverse implications for institutional and governmental legitimacy (World Bank, 2002). The significance of political corruption as a threat to the legitimacy of government underscores its recognition in the literature as a major determinant of citizen's trust and distrust in government and democracy (Iroghama, 2012).

The capacity of political corruption to erode public trust in government and support for democracy is strong (Diamond 2008). Public trust here means citizen's confidence and support for government, political institutions, and politicians upon evaluation of their performance and policies (Irogham, 2012). Public trust in government and politicians is fundamental for citizens' cooperation towards the realisation of government policies and national development (Khan, 2007). The delivery of socio-economic and political goods enhances public trust in a democratic government. Conversely the poor performance of the government in the delivery of public goods endangers its legitimacy (Alemika, 2004). Therefore, the danger political corruption poses to the legitimacy of government by its devastating impact on socio-economic and political development and obstruction of the wheel of good governance can be appreciated in this context.

\section{Political Corruption, Government Legitimacy and Democracy in Nigeria}

The return to democracy in 1999 has failed to produce the democratic dividends envisaged by most Nigerians (Afrobarometer, 2006). Political corruption constitutes a major obstacle to the enjoyment of the benefits of democracy in Nigeria. It has constrained economic development and undermined poverty reduction. It has sabotaged good governance, subverted the sanctity of the electoral process and undermined responsive governance. The problems of massive unemployment, social unrests and violence are major outcomes of widespread political corruption in Nigeria (Ogundiya, 2010; Aliu, 2013; Aliu, 2018).

Public support and trust in political authorities, institutions and personalities are crucial to the legitimisation of democracy in Nigeria (Alemika, 2004: 27). The observed debilitating consequences of political corruption in Nigeria have been confirmed in the literature to have negatively affected public trust on democratic institutions and government legitimacy. Suberu in (Ogundiya, 2009) argued that the sabotage of popular aspirations for good and responsible governance caused by political corruption portrays government as incapable of delivering public goods and deepens citizen's distrust of government in Nigeria. Moreover, the lack of accountability and 
misrule resulting from the perversion of the electoral process affects the active participation of some Nigerians in government activities (Ogundiya, 2010). Besides, the absence of popular participation in governance undermines civil society's support for government and invariably the legitimacy and stability of government and democracy in Nigeria (Fagbadebo, 2007).

Afrobarometer dataset on the effects of political corruption on public perception of political authorities and institutions provides a robust empirical evidence for understanding the political corruption, legitimacy of government and democracy connection in Nigeria. The 2001 and 2003 Afrobarometer surveys for example showed that most Nigerians perceived most public officials as corrupt (Alemika, 2004), indicating the likelihood of low public trust in government. To establish the effects of political corruption on institutional trust in Africa, Attoh, Gyimah-Boadi and Chikwanha (2007, iii), using a statistical analysis on Afrobarometer data survey of twelve African countries including Nigeria concluded that corruption is 'the major obstacle to building popular trust in state institutions and electoral processes' in the countries studied and Nigeria. Equally, Attoh, Gyimah-Boadi and Chikwanha, (2007) demonstrated that popular perception about widespread political corruption in Nigeria has undermined public trust in state institutions like the presidency, electoral commission, parliament and local governments.

Moreover, the Afrobarometer dataset used in the study to assess the corruption and institutional trust nexus in each country provides glaring evidence of the deleterious effect of political corruption on public trust on democratic institutions in Nigeria. For example, public trust in the presidency in Nigeria declined to 26\% in 2005 (Attoh, Gyimah-Boadi and Chikwanha, 2007) contrary to the $72 \%$ obtained in 2001 (Afrobarometer, 2006; Diamond, 2008). Similarly, the approval of Nigerians for the ruling People's Democratic Party fell from $71 \%$ to $55 \%$ during the same period (Afrobarometer, 2006). Furthermore, public trust in the National Assembly dropped to 22\% in 2005 (Attoh, Gyimah-Boadi and Chikwanha, 2007) indicating a decline from the $67 \%$ obtained in 2001 (Afrobarometer, 2006). Similarly, public trust in the electoral commission (INEC) plummeted to 23\% in 2005 (Attoh, GyimahBoadi and Chikwanha, 2007) from the 66\% of 2001 (Afrobarometer, 2006). Significantly and with serious implications for the legitimacy of elected political leaders in Nigeria, only 32\% Nigerians felt that elections in the country were free and fair by 2005 (Attoh, Gyimah-Boadi and Chikwanha, 2007).

Furthermore, Lavallee, Razafindrakot and Roubaud (2008) statistical analysis of the effects of corruption on public trust in institutions of government in sub-Saharan Africa indicated that Nigerians have low trust in political institutions. The Afrobarometer dataset used in the study revealed that the percentage of Nigerians with no trust in any political institutions due 
to corruption in 2002 and 2005 were $67 \%$ and 54\% respectively, the lowest in Africa during the reviewed period (Lavallee, Razafindrakot and Roubaud, 2008). Besides, the perception of Nigerians of widespread political corruption contributes to the low public confidence in the capacity of government to tackle socio-economic and governance challenges. For example, the percentage of Nigerians confident in the ability of government to effectively narrow the gaps between the rich and poor declined from $40 \%$ in 2000 to $10 \%$ in 2005, while public trust in the ability of government to effectively meet the educational challenges of the people fell from $63 \%$ in 2001 to $40 \%$ in 2005 (Afrobarometer, 2006). The adverse impact of corruption on the policy performance of government as indicated by the Afrobarometer survey has dire implications on public perception of government capacity to deliver public goods, and the working of democracy in Nigeria. For example, the percentage of Nigerians that expressed satisfaction with the performance of democracy in the country declined from $84 \%$ in 2000 to $25 \%$ by 2005 (Afrobarometer, 2006).

Notwithstanding the dissatisfaction of most Nigerians with the performance of elected leaders and institutions, public support for democracy is strong although it is on the decrease. The percentage of Nigerians who express preference for democracy in 2001 was $81 \%$, but this has gradually declined to $65 \%$ by 2005 (Afrobarometer, 2006). This evidence is consistent with Diamond (2008) argument that corruption erodes public trust in government and can encourage citizens to reject democracy, and corroborates Attoh, Gyimah-Boadi and Chikwanha (2007, iii) proposition that low public trust in government and democratic institutions resulting from widespread political corruption hinders the 'development of mass attitudes supportive of democracy'. Drawing from the foregoing descriptive and empirical analysis, political corruption is a significant predicator of public trust in Nigeria. The decline in the perceptions of Nigerians on the performance of government and political institutions since the return of democracy can be linked to the devastating consequences of pervasive political corruption (Attoh, GyimahBoadi and Chikwanha, 2007, 10). This has resulted in the significant decline in popular support for government institutions, policies, politicians and legitimacy of democratic governance in Nigeria despite the support for democracy by most Nigerians (Afrobarometer, 2006).

\section{Conclusion}

Corruption among public officials and political leaders is widespread and poses a serious threat to democratisation in Nigeria. The paper contends that the activities of the ruling elites are core to understanding the alarming dimension that corruption has assumed in the polity. In the context of the power relations inherent in the society, the ruling elites largely regards the 
abuse of state power, offices, resources, funds, legislations and institutions as the main available means to the acquisition, use and consolidation of political powers. So, the appropriation of state power and resources for private gain readily becomes a culture among public officials and political leaders necessary to sustain the networks of relationships, and amass resources necessary to entrench their hold on state power - sustenance of political power by any means necessary.

The transitional nature of democracy implies that there must be a favourable environment to enhance the deepening of democratic values in Nigeria. But, the scourge of widespread corruption continues to undermine the rule of law, accountability, transparency, strong and independent institutions, credible elections and other democratic values in the country. The mix of poverty, unemployment, electoral violence, insecurity, political instability, and economic hardships which are partly the outcome of endemic corruption in the polity continue to undermine popular trust in government, institutions and the political system in Nigeria. Political corruption is a major factor that explains the decline in public confidence in politicians, the democratic processes and institutions and the slide towards democratic reversal and political authoritarianism.

Drawing from the contention of the paper, the problem of endemic political corruption in Nigeria is essentially a political problem. This is because corruption can largely be situated among the ruling elites who control political power and resources. Therefore, any suggestions aimed at addressing the problem of corruption in the polity should largely involve politics. First, there is the need for the rebirth of the political leadership in Nigeria. In this context:

The political leadership must come to accept politics as a rare opportunity to offer honest and accountable services to the nation. The attitudinal rebirth of the ruling elites should come more from the deep self reflection and realization of how the other politics - politics driven by greed and avarice have left the country backward and made it a laughing stock in the comity of nations. The ruling elites must provide purposeful leadership, predicated on national rebirth, economic development and fostering of democratic values, devoid of parochial and primordial sentiments (Aliu, 2018: 149).

Therefore, the ruling elites should stop regarding politics as the only avenue to making money in Nigeria. This will go a long way in making elite contestation for political power decent, devoid of underhand manipulations and the undue influence of money. This will strengthen the practice of internal democracy among political parties in the long run. The ruling elites will have 
to foster the political will to invigorate the antic-corruption crusade in the country, by ensuring that activities of anti-graft agencies are whole heartedly supported and devoid of partisan interference (Aliu, 2011; Aliu, 2013; Aliu, 2018).

\section{References:}

1. Adesina, O. S. (2016).Nigeria and the burden of corruption, Canadian Social Science, 12(12): 12-20

2. Afrobarometer. (2006). Performance and legitimacy in Nigeria's new democracy, Afrobarometer Briefing Paper No. 46, July.

3. Alabi, M. O. A. and Fashagba, J. Y. (2010). 'The legislature and anticorruption crusade under the fourth republic of Nigeria: Constitutional imperatives and practical realities', International Journal of Politics and Good Governance, 1(1.2) Quarter II, Pp 1 - 39.

4. Aleimika, E. (2004). 'Corruption, governance performance and political trust in Nigeria', CSSR Working Paper No. 77. Centre for Social Science Research University of Cape Town.

5. Aliu, M. (2011). Towards depoliticizing the activities of anticorruption agencies in Nigeria for effectiveness, NASHER Journal, 9(1): 102-108.

6. Aliu, M. (2013). Legislative corruption and democratic consolidation in the Nigerian fourth republic, Journal of Sustainable Development in Africa, 15(6): 101-112.

7. Aliu, M. (2014). The State, development and governance in Africa: The Nigerian experience, IOSR Journal of Humanities and Social Sciences (IOSR-JHSS) 19 (4) Ver. I

8. Aliu, M. (2018). Political corruption, economic development, and democracy in Nigeria, 1999 - 2015, Journal of Contemporary and Social Research, 3(1): $173-178$.

9. Armah-Attoh, D, GyimahBoadi, E and Chikwanha, A. B. (2007). 'Corruption and institutional trust in Africa: Implications for democratic development', Afrobarometer, Working Paper No. 81

10. BBC. (2012). Former Nigeria governor James Ibori jailed for 13 years (Online), Available from: www.bbc.co.uk/news/worldafrica17739388, 17 April, 2012.

11. Diamond, L. (2008). The spirit of democracy: The struggle to build free societies throughout the world. New York: Henry Holt and Company.

12. Ekundayo, W. J. (2017). Political Elite Theory and Political Elite Recruitment in Nigeria, Public Policy and Administration Research, 7(5): $1-8$. 
13. Fagbadebo, O. (2007). 'Corruption, governance and political instability in Nigeria', African Journal of Political Science and International Relations, 1 (2): 028 - 037.

14. Gardiner, J. (2009). 'Defining corruption', in A. J. Heidenheimer and M. Johnston (eds) Political corruption: Concepts and contexts (Third edition) $5^{\text {th }}$ printing, New Brunswick: Transaction Publishers, Pp $25-$ 40.

15. Grugel, J. (2002). Democratisation: A critical introduction, New York: Palgrave Macmillan Human Rights Watch. (2011). Corruption on Trial? The Record of Nigeria's Economic and Financial Crimes Commission, New York, USA: Human Rights Watch, August, Pp 164.

16. Inokoba, P. K. and Ibegu, W. T. (2011). 'Economic and Financial Crime Commission (EFCC) and political corruption: Implications for the consolidation of democracy in Nigeria', Anthropologist, 13(4): 283 $-291$.

17. Iroghama, P. I. (2012). 'Trust in government: A note from Nigeria', International Journal of Academic Research in Economics and Management Sciences, 2(1): 258-267.

18. Joseph, R. (1991). Democracy and prebendal politics in Nigeria, Ibadan: Spectrum Book Ltd.

19. Khan, M.A. (2007). 'Building trusts in government: Concepts and issues', in Building trusts through civic engagement, Publication based on the 7th Global Forum workshop on Building Trust through Civic Engagement 26 to 29 June 2007 Vienna, Austria, ST/ESA/PAD/SER.E/120 United Nations Publications, (Online). (Accessed on 20 June, 2012), Available from: http://unpan1.un.org/intradoc/groups/public/documents/undpadm/unpan028357.pdf

20. Klitgaard, R, Maclean-Abaroa, R. and Parris, H. L. (2000). Corrupt cities: A practical guide to cure and prevention, A publication of Institute for Contemporary Studies (ICS) and World Bank Institute.

21. Lavallee, E, Razafindrakoto, M and Roubaud, F. (2008). Corruption and trust in political institution in sub-Saharan Africa, DIAL DUCUMENT DE TRAVIAL DT /2008-07, Pp 1-21. Available from: www.dial.prd.fr/dial_publications/PDF/Doc_travail/2008-07.pdf

22. Lipset, S. M. (1959). 'Some social requisites of democracy: Economic development and political legitimacy', The American Political Science Review 53(1): $69-105$.

23. López, M. (2013). Elite theory, sociopedia.isa, $1-12$.

24. Mustapha, M. (2010). Corruption in Nigeria: conceptual and empirical notes, Information, Society and Justice, 3(2): 165 - 175. 
25. Ogundiya, I. S. (2010). 'Corruption: The bane of democratic stability in Nigeria', Current Journal of Social Sciences, 2(4): 233 - 241.

26. Ogundiya, I. S. (2009). 'The cycle of legitimacy crisis in Nigeria: A theoretical exploration', Journal of Social Sciences, 20(2): 129-142.

27. Okeke, R. C. and Idike, A. N. (2016).The dialectics of political economy and elite corruption in a postcolonial State: A Nigerian case study, Kuwait Chapter of Arabian Journal of Business and Management Review, 5(7): 55 - 60.

28. Omodia, S. M (2011). Political elites and the challenge of free and fair elections in the nigerian fourth republic, Canadian Social Science, 7( 5): 111-115

29. Schumpeter, J. A. $2^{\text {nd }}$ edition. (2011). Capitalism, socialism and democracy, New York: Harper.

30. Szeftel, M. (2000). 'Between governance and underdevelopment: Accumulation and Africa's 'Catastrophic Corruption', Review of African Political Economy, 84: 287 - 306.

31. Thisday. 2011. Bode George, five others leave Kirikiri prisons tomorrow, (Online), Available from: www.thisdaylive.com, 25 February, 2011.

32. World Bank. 1997. World Development Report 1997: The state in a changing world, Oxford: Oxford University Press.

33. World Bank. 2002. World Development Report 2002: Building institutions for markets, Oxford: Oxford University Press. 